JUSTYNA SZYMAŃSKA (D) https://orcid.org/0000-0002-0984-7828

Uniwersytet Warszawski

\title{
Od tradycyjnych pasterzy do transrelacyjnych społeczności. Mongolska sztuka nieformalnego
}

\section{RECENZJA}

Rakowski, Tomasz (2019). Przeptywy, współdziałania, kręgi możliwego.

Antropologia powodzenia. Seria „Idee i Etnografia”. Gdańsk: słowo/obraz terytoria.

$P$ rzepływy współdziałania, kręgi możliwego. Antropologia powodzenia to druga autorska monografia w dorobku dr. hab. Tomasza Rakowskiego, po wyróżnionej Nagrodą im. ks. Józefa Tischnera książce Łowcy, zbieracze, praktycy niemocy. Etnografia człowieka zdegradowanego (2009). Autor jest etnologiem, antropologiem kultury, kulturoznawcą pracującym w Instytucie Etnologii i Antropologii Kulturowej Uniwersytetu Warszawskiego, współpracującym także z Instytutem Kultury Polskiej Uniwersytetu Warszawskiego. Jest również praktykującym lekarzem. Wcześniejsza autorska książka przyniosła mu rozpoznawalność, także poza środowiskiem naukowym, jako eksperta od antropologicznych badań nad ubóstwem. Tomasz Rakowski w ostatnich latach jest jednak również znany jako badacz procesów animacyjnych w społecznościach lokalnych, a także praktyk etnograficznie zorientowanej animacji kultury, co przybliża w redagowanych i współredagowanych przez siebie tomach zbiorowych Humanistyka $i$ dominacja. Oddolne doświadczenia społeczne w perspektywie zewnętrznych rozpoznań (2011), Etnografia/animacja/sztuka. Nierozpoznane wymiary rozwoju kulturalnego $(2013,2015)$ czy anglojęzycznej Pretextual Ethnographies: Challenging the Phenomenological Level of Anthropological Knowledge-Making (2018). Interesuje się również antropologią współczesnej sztuki partycypacyjnej, w tym jej wykorzystaniem w działaniach 
animacyjnych, a także badaniem oddolnych procesów rozwojowych. To właśnie temu ostatniemu zagadnieniu poświęcona jest książka Przeptywy wspótdziałania, kręgi możliwego. Antropologia powodzenia. Osadzona w dalszej geograficznie rzeczywistości niż poprzednia monografia autora, jest równie ciekawa, aktualna i proponująca świeże spojrzenie na dobrze, wydawałoby się, poznane i opisane kwestie oddolnych form rozwoju i aktywności obywatelskiej.

W Przeptywach wspótdziatania... Rakowski zabiera czytelników w podróż do Bułganu, somonu (mongolskiej jednostki administracyjnej) zamieszkanego w większości przez Torgutów, zróżnicowaną grupę będącą odłamem Mongołów zachodnich. Ich życie, nieformalne praktyki przysług i współdziałania, strategie radzenia sobie i oddolnego budowania rozwoju po okresie postsocjalistycznej transformacji są głównymi tematami prowadzącymi czytelnika przez gęsty opis bułgańskiej rzeczywistości. Przede wszystkim zaś książka jest zapisem odkrywanego wielowarstwowego "faktu etnograficznego", jakim jest torgucka nieformalność i tworzona przez nią lokalna wizja rozwoju - w relacji z państwem, innymi ludźmi, a może przede wszystkim w relacji z emicznymi ideami „możliwości” $\mathrm{i}$ „powodzenia”.

Książka składa się z obszernego wprowadzenia teoretycznego oraz czterech rozdziałów zestawiających teorię $\mathrm{z}$ wiedzą terenową. $\mathrm{W}$ otwierającym książkę wprowadzeniu Rakowski poświęca sporo miejsca na opisanie różnorodnych teorii i definicji pojęć, takich jak rozwój, współdziałanie, nieformalność czy obywatelskość, które w następnych rozdziałach ożywia i ilustruje przykładami ze swoich badań terenowych w zachodniej Mongolii. Jednym z ważniejszych fenomenów, które autor najpierw opisuje z perspektywy teoretycznej, a następnie obserwuje w terenie, jest "lokalna wizja rozwoju”, która wnikliwie opisana w przywoływanych przez autora przykładach Davidéa Mossa i Jamesa Fergusona niemal nigdy nie jest prostą narracją „powodzenia” lub „niepowodzenia” misji rozwojowej.

Rakowski wykorzystuje to pojęcie, aby pokazać później na empirycznym przykładzie mongolskim, że każde działanie zewnętrzne przecina się nie tylko z lokalną wiedzą i praktyką, celami miejscowych organizacji politycznych, państwowymi politykami lokalnymi oraz innymi podmiotami społecznymi i politycznymi, ale także „oporem i przechwytywaniem możliwości, jakie oferują nowe relacje ekonomiczne, nowe programy i warunki działania" (Rakowski 2018: 30). W rozdziale czwartym poświęconym lokalnym formom rozwoju, nieformalnym działaniom i wytwarzaniu państwa Rakowski pokazuje te zależności na poziomie etnograficznym na przykładzie badanej społeczności Bułganu.

Tę upraszczającą, ale wciąż żywą dychotomię „powodzenia” bądź „niepowodzenia" programów rozwojowych, stworzonych i realizowanych przez pozalokalnych aktorów - najczęściej dużych, międzynarodowych agencji - autor zastępuje pojęciem rozwoju endogennego. Tak zdefiniowany rozwój jest nie tylko procesem interakcji i łączenia różnych światów, ale wręcz „,uginania się wiedzy antropologicznej i naukowej, konieczności przyswojenia sobie innej wiedzy i innej logiki oraz przyłączenia jej do tego, co wiąże się z rozwojem, z działaniami na rzecz przebudowy ekonomicznej, społecznej i kulturowej w krajach i społeczeństwach 
odbierających pomoc rozwojową" (Rakowski 2018: 37). Autor zwraca przy tym uwagę na różnicę między wiedzą lokalną, która pozostaje jedynie rozpoznana, ale nie włączona w działania rozwojowe, a taką, która co prawda jest włączana $\mathrm{w}$ te procesy, lecz następnie sama przechwytuje narzucone odgórnie praktyki i dyskurs rozwojowy.

Ta ostatnia sytuacja często skutkuje różnymi formami lokalnego oporu, a w efekcie skategoryzowaniem projektu jako „niepowodzenia” lub działania przynoszącego bądź co bądź pozytywne (z punktu widzenia nadzorujących proces agencji), lecz niespodziewane efekty. W obu przypadkach ścieranie się oddolnych i odgórnych polityk rozwojowych jest silnie naznaczone relacjami władzy, w których oczywistą przewagę mają międzynarodowe, dobrze finansowane agencje.

Rakowski w swojej monografii zwraca jednak uwagę na sytuację, w której to lokalna wiedza i praktyki są na tyle silne, że to one nie tylko przechwytują niejako narzucane im procesy rozwojowe i modernizacyjne, ale też wytwarzają własne, żywiołowe procesy samoorganizacji, które można nazwać właśnie „lokalnymi formami rozwoju” czy też „rodzajami rozwoju endogennego”. To właśnie je autor typuje na główne przyczyny zmian, jakim podlega społeczeństwo. Jest to więc wyraźne podkreślenie podmiotowości działań oddolnych, wyrastających z historycznych, społecznych i kulturowych idiomów danej społeczności - lokalnych, wewnętrznych logik rządzących akceptowalnymi strategiami i praktykami życia - raczej niż tych odgórnych, przybyłych z innych kontekstów. Takim przykładem jest właśnie odwiedzony przez badacza torgucki somon, funkcjonujący przez historycznie ukształtowane „idiomy współdziałania i wspólnego użytkowania dóbr" z jednej strony oraz „sztukę nieformalnego" opartego na więziach krewniaczych z drugiej. Zarysowany tak obraz jest bardzo ciekawą analizą potwierdzającą przyjętą przez autora tezę.

Po części teoretycznej w kolejnych rozdziałach autor skupia się na opisaniu historycznego i społecznego kontekstu zmian zachodzących we współczesnej Mongolii. Rakowski wnikliwie analizuje wpływ nagłych i często dramatycznych dla obywateli byłego ZSRR zmian, jakimi były rozpad Związku Radzieckiego oraz następujące po nim transformacje ustrojowe i gospodarcze. W konsekwencji tych wydarzeń w Mongolii, tak jak w wielu innych byłych radzieckich republikach, pojawiło się „,żywiołowe, chaotyczne działanie handlowe i biznesowe, obciążone w Mongolii znaczeniem pracy pobocznej, mniej wartościowej, a przy tym podejrzanej moralnie w kontekście historycznych zaszłości (...)" (Rakowski 2018: 99).

Dla zrozumienia opisywanego mongolskiego kontekstu istotny jest właśnie wspomniany przez autora fakt „historycznej zaszłości”, czyli żywej pamięci kulturowej społeczeństwa, które swoją tożsamość budowało na etosie ludu pasterskiego. Zmiany związane z transformacją zmusiły Torgutów do zajęcia się handlem, profesją do tej pory postrzeganą jako coś odpowiedniego raczej dla przygranicznych społeczności Chińczyków. Handel do niedawna traktowany był przez Mongołów lekko pogardliwie, a pogarda ta była podszyta uwarunkowaną historycznie, mongolską „,sinofobią”, jak określa ją w książce autor. 
Co ciekawe, dla czytelnika mniej obeznanego z kontekstem mongolskim, zmiany systemowe lat dziewięćdziesiątych, które przez mieszkańców europejskiej części Związku Radzieckiego są często wspominane jako trudne, naznaczone ekonomiczną i polityczną niepewnością, w pamięci Torgutów funkcjonują w sposób dużo bardziej niejednoznaczny. Ma to związek zarówno z innym traktowaniem czasu - mniej teleologicznym, linearnym niż w tradycji europejskiej - jak i bogactwem znaczeń nadawanych nieformalnym praktykom, które w społeczeństwach zachodnich często bezkrytycznie wrzucane są do kategorii "korupcji”, „nepotyzmu” czy „nielegalnych interesów”.

W Mongolii kwestie własności (czy też raczej współwłasności) i ekonomicznego współdziałania łączą się z porządkiem społecznym i porządkiem władzy, a sfera polityczna nie jest wyraźnie oddzielona od sfery ekonomicznej, prywatnej czy postawy dbania o powodzenie własne i swojej rodziny. Jak pisze cytowany w książce David Sneath (2003: 200): „Wielokrotnie widziałem, jak uderzające było dla ludzi Zachodu to, do jakiego stopnia lokalni urzędnicy (lokalne władze) wciąż pozostawali zaangażowani w niemal każdą operację ekonomiczną". Ta umiejętność pozwoliła młodemu i średniemu pokoleniu bułgańskich Torgutów na stworzenie skutecznych sieci handlowo-biznesowych rozciągających się z rodzinnego somonu do „Miasta” (jak nazywana jest stolica, Ułan Bator), jak i za granicę - przede wszystkim do przygranicznych Chin.

To nieformalne działanie i nieformalne przysługi są czymś więcej niż nieuregulowaną prawnie transakcją ekonomiczną - są wyjątkowym i skomplikowanym splotem wdzięczności, szczodrości, pamięci, sztuki „bycia kimś” (lub nawet „bycia sobą"), budowania teraźniejszych i przyszłych relacji i możliwości. Wejście $\mathrm{w}$ nieformalność to swoista gra naznaczona ryzykiem - ryzykiem przegranej i przemocy - ale także nadzieją i szansą, jakiej nie dają oficjalne, formalne drogi działania. Jak pisze autor, „sztuka nieformalnego jest sztuką nie tylko osiągania celów, lecz także budowania pozycji, budowania siebie w oczach innych" (Rakowski 2018: 139).

To właśnie rozgrywane i konceptualizowane przez samych zainteresowanych ryzyko i szanse wpisane $\mathrm{w}$ nieformalność sprawiają, że przywołane w książce relacje tytułowych współdziałania i możliwości nadają rozszerzonemu krajobrazowi społecznemu Bułganu rys kosmologiczny. Przy całym bogactwie relacji nieformalnych nie są one bowiem, jak mogłoby się to wydawać na pierwszy rzut oka osobom przyzwyczajonym do zachodniocentrycznej dychotomii prywatnego i publicznego przeciwstawione państwu. Państwo, jak przekonuje Rakowski, jest przez Mongołów postrzegane raczej jako ożywcze źródło porządku i harmonii, a nieformalne działania oddolne nie są jego przeciwieństwem, lecz harmonijnie funkcjonującym uzupełnieniem, jako że mogą służyć wspólnemu, nadrzędnemu celowi - usprawnieniu przepływów współdziałania i poszerzeniu kręgów możliwego.

Bardzo często ten fakt jest trudny, jeśli nie wręcz niemożliwy do zrozumienia dla europejskich, lub szerzej - zachodnich organizacji rozwojowych i instytucji, które działają w Mongolii i starają się wcielać tam w życie swoje modele 
polityk rozwojowych. Mongolskie praktyki bywają więc przez osoby z zewnątrz postrzegane jako nielegalne, a bywa, że wręcz mafijne powiązania, które rozumiany na modłę zachodnią rozwój hamują, a nie go usprawniają i dopasowują do lokalnych warunków. Jak bardzo jest to redukcjonistyczny i ograniczony wgląd w lokalną kulturę, przekonujemy się coraz bardziej w miarę czytania napisanej przez Rakowskiego gęstej etnografii i wnikliwej antropologicznie analizy tego zjawiska.

W swojej książce autor przedstawia przenikanie się formalnego i nieformalnego, stawiając pytanie o to, jak jeszcze można opisać antropologiczny namysł nad istotą państwa oraz splotów ludzkich i pozaludzkich relacji, przywołując zarówno starsze, jak i nowsze teorie z zakresu antropologii rozwoju, polityki czy państwa. Jego postulatem jest perspektywa „antropologii powodzenia” obejmująca torgucką kosmologię w wymiarze obywatelskiej (i nie tylko) aktywności, mającej siłę wchłaniania i przekształcania zewnętrznych, często narzuconych wzorców na te lokalnie zakorzenione i oswojone, znacznie trwalsze i często bardziej efektywne. Dążenie do zapewnienia sobie powodzenia - jak przekonująco opisuje Rakowski - jest równocześnie tęsknotą i pragnieniem wytworzenia (lub odtworzenia) idealnego świata społecznego czy też „dobrego", „właściwego" życia.

Przeplatające się w Przepływach współdziałania, kręgach możliwego liczne przykłady zaobserwowanych w terenie zjawisk oraz ich analiza są na tyle gęste, że czasem można zgubić się w proponowanych przez autora wątkach. Na szczęście podsumowanie w ostatnim rozdziale, ponowne, całościowe ujęcie tropów prezentowanych przez autora w miarę pisania książki, pomaga dobitnie wybrzmieć proponowanej przez badacza tezie. Omawiana monografia prezentuje świeże i nieszablonowe podejście do interpretacji zjawisk, które z pewnością zaobserwowało w Mongolii wielu badaczy. Jednak podejście do tradycyjnych idiomów działania i znaczeń nadawanych współczesnym zjawiskom przez społeczności do tej pory tradycyjnie pasterskie z perspektywy teorii rozwoju, „odtwarzania” państwa (czy też działania ,jak państwo”) czy nieformalnej ekonomii, jak to zrobił Rakowski, jest inspiracją do podobnie otwartego spojrzenia na szeroko rozumianą tradycję także $w$ innych kontekstach.

W publikacji nie brakuje inspirującego podsumowania najciekawszych teorii związanych z zagadnieniami antropologii rozwoju, antropologii nieformalności, idei społeczeństwa obywatelskiego, w tym jego percepcji i adaptacji w innych niż zachodnie kontekstach, lokalnych systemów zaufania, współdziałania czy taktyk bycia-w-świecie. Książka jest cennym źródłem także dla osób bardziej zainteresowanych kontekstem stricte mongolskim, zwłaszcza zachodzącymi ostatnio w tym kraju zmianami społecznymi oraz tym, jak nomadycznym do niedawna społecznościom udaje się płynnie przechodzić od życia w tradycyjnych pasterskich somonach do funkcjonowania w transrelacyjnych i transgranicznych społecznościach, zachowując przy tym swoje wartości, normy i tradycyjne rozumienie tego, co możliwe i korzystne. 